\title{
Scholar, Heal Thyself; or \\ How Everybody Got to Be an Expert on the Bible
}

\section{Richard Elliott Friedman}

It is a strange fact that we biblical scholars always seem to meet people who are surprised to hear that we really know things about the Bible. They assume that the study of the Bible is a matter of opinions and interpretations, with few verifiable facts one way or another. Even though the archaeological revolution is about a century old, even though the advances in language, text, artistry, and history are reported in thousands of books of introduction, history, and commentary, people just do not conceive of biblical scholars as having the kind of expertise that professionals in medicine or law -or even other scholars in the sciences or the humanitieshave.

And so oddball theories make the front pages of respectable newspapers and magazines. Archaeological discoveries are misinterpreted or blown out of proportion. Absurd computer programs are received as legitimate analyses. One view is as good-meaning as unprovable-as another. There is also Exodus Fever, a term used in the field for the phenomenon of persons from a variety of fields who are attracted to explain the events of the exodus and Sinai stories with what they believe to be new insights from their own areas of knowledge: geologists, astronomers, Egyptologists, oceanographers, psychologists, historians of other periods and places. The temptation to explain the splitting of the Red Sea, the plagues, and the fiery mountain is irresistible. Everyone explains the Bible - and not hesitantly, or modestly, but like an expert. They are going to show us what the real experts have been missing.

This must happen to some extent in most every other field as well. I suppose that medical doctors have to endure being told about amazing cures for diseases that the medical profession has failed to recognize. Probably almost everyone has been told how he or she could do his or her job

\footnotetext{
* An earlier version of this essay appeared in Bible Review, April, 1991. The present version appears here with the permission of Bible Review, 3000 Connecticut Avenue N.W., Washington, DC 20008.
} 
better - that is, told by someone who has never done that job. But I think that there is a quantitative difference when it comes to professional scholars of the Bible. I cannot think of any other area that so many persons from so many other fields try to practice. From Freud to Velikovsky to Isaac Asimov to Mary Douglas to Northrop Frye, and most recently Harold Bloom: when it comes to doing a subject in which one is not trained, the study of the Bible is in first place (and the study of Freud probably second). A recent $B B C$ program on the literary study of the Bible included comments from a philosopher, an anthropologist, novelists, a playwright, a rabbi, a nun, and a scribe-everyone but a person who was actually a trained specialist in the literary study of the Bible. The mystery writer P. D. James referred to the Bible in that program as "The greatest work of English literature." English literature? Yes, but you really must admit that our Hebrew and Greek translations do a wonderful job of capturing the spirit of the original.

The results vary. Freud's Moses and Monotheism is remarkably insightful and of enormous instructive value even if Freud was mistaken on individual points - as he was perfectly willing to acknowledge. Most amateur contributions are less helpful.

Do all of these people have a right to their opinions about the Bible? Sure. They have a right to opinions about law and medicine, too; but if you have chest pains I suggest that you see a cardiologist, not Harold Bloom; and, as they say, anyone who acts as his own lawyer has a fool for a client.

Why do they do it? Because it is the Bible, of course. It is a book of power, beauty, and, most important for this question, mystery. It is not literature in the way that The Brothers Karamazov or Hamlet is literature. It is sacred literature. What makes a book sacred is the way in which it merges literature and history (both the history in it and the history of it). Because of the special nature of the history that the Bible recounts, and because of the special role that the Bible has played in human history, it has come to be held as sacred. Even those who do not believe in the literal accuracy of every word in the Bible still respond to it differently from the way they respond to The Great Gatsby. It has a unique status. The practical result of a book's acquiring such status as sacred literature is that it has authority. There is thus more power in controlling the Bible than in con- 
trolling Proust or even Tolstoy or even Homer. The Bible is a prize to be had. The Bible is also a wonder and a joy. And so it attracts both the noble and the ignoble to try to capture it - in both senses of the word "capture."

The latest group to enter the lists of those who want to capture the Bible is literary scholars. The results have been mixed, including some truly useful, stimulating contributions and some flights of almost unbelievable ignorance. The attempt at literary study of the Bible that has received the most attention in the media by far is the catalyst of this collection of essays. It is by a professor of English, Harold Bloom, and a poet, David Rosenberg. It is called The Book of J, and it is a scandal.

Bloom and Rosenberg claim to have isolated the text known in the documentary hypothesis as $\mathrm{J}$, an incomplete but still substantial work which was woven in with other ancient works to form the Five Books of Moses. They claim that Rosenberg has produced a new and far superior English translation of the work. The book jacket says that Bloom and Rosenberg have lifted the J text out of the surrounding material for the first time. The publicity announces that Bloom has boldly proposed the idea that the $\mathrm{J}$ text was written by a single author and that this author was a woman.

I am not focusing on this book for the usual purposes of a book review. I am rather interested in it as a touchstone that reveals what really concerns me, namely the current degree of ignorance about the Bible.

This book has been treated as an event. There were stories about it in Time, Newsweek, and U.S. News \& World Report. The New York Times ran four separate pieces on it. Bloom and Rosenberg were interviewed on leading radio and television news/talk programs (in one case along with me). In a matter of months it had several printings. It was on the best seller list.

The publisher's publicity claimed that the book would outrage scholars, but most scholars I know who cared about it at all were simply amused or, at most, annoyed. They saw it as another book by untrained persons trying to be experts on the Bible. As it was reviewed by other untrained persons in the popular press, the whole thing just seemed surreal, the uninformed critically evaluating the uninformed.

The problem: (1) The text that appears in Bloom's and Rosenberg's 
book is not J. (2) The "translation" is not a translation at all. It is a retelling of the Bible's stories in Rosenberg's own words, a sort of mistaken paraphrase of what the Bible really says. As the humorist Dave Barry would say: I am not making this up. I am not even exaggerating. The text that they are calling $\mathrm{J}$ is not $\mathrm{J}$, and the words of that text are not the words of the Bible.

THE TEXT THAT APPEARS IN THE BOOK IS NOT J. A few years ago I described the rather complex method by which scholars came to separate several works that appeared to be combined with one another to form the Five Books of Moses (in Who Wrote the Bible?, 1987). It is a combination of linguistic, literary, historical, and archaeological analyses, a process that we have been refining for centuries. By linguistic analysis, developed in the last twenty years, we can determine the relative period in which each of the works was written. By historical and archaeological analysis we can uncover the referents of stories in these works, and we can relate the stories to their authors' concerns at particular moments in history. By literary analysis we can recover the narrative continuity of each work, identify the puns, denouements, and ironies that bind each work, and identify the characteristic terms and phrases that the authors of each of these works deployed. Either to accept or reject the documentary hypothesis today thus requires much training and a sophisticated complex of skills.

Bloom and Rosenberg simply were not in command of these skills. They had no way of separating the J stories from the stories that were written in a later stage of biblical Hebrew. They were not sufficiently familiar with the major groups and events of Israelite history to be able to relate individual stories to one background or another. And they made elementary errors in recognizing the characteristic language and interests of $J$ and the other works. The result: they cut out major parts of $J$, and they included stories that are from other works, not J. It is like giving us a text of Tolstoy's Anna Karenina that has sections of the text missing and has pieces of The Brothers Karamazov and Fathers and Sons inserted instead.

Bloom and Rosenberg included the story of Moses and seventy elders who go up the Mountain of God and have a vision of the deity. But this story is not J. It is from another work by another author. In this story, the deity is referred to by the narrator as "God." But one of the marks of $\mathrm{J}$ is 
that it does not use the word "God" (Hebrew: Elohim) in narration. Humans in J say the word in dialogue, but the narrator does not use it. That is one of the reasons why we call it "J," which stands for the name that this narrator consistently does use for the deity: Yahweh (Jahwe in the German spelling, hence the J). The work that calls the deity Elohim is known as "E."

Bloom and Rosenberg included part of the story of Moses and the golden calf, thinking that it is part of J. In the golden calf story, the narrator calls the deity Elohim. It is one continuous story, all E. In Who Wrote the Bible?, I said that it is in fact the most revealing of all the $\mathrm{E}$ stories with regard to the E author's identity. Bloom and Rosenberg decided that part of the story was J, broke the story in the middle, and included only that small part of it. The result is a mess. They cut out the part in which Aaron makes the golden calf, but they still have Moses coming down from the mountain and seeing the calf, which has come from nowhere. They cut out the part in which the deity gives Moses the tablets, but they have Moses now smashing the tablets in his anger. To solve part of this they take the real $\mathrm{J}$ story of the making of the tablets, which comes later, and they reverse the order of the biblical text and attach it to the beginning of the golden calf story. This makes things even worse; now it is not only a narrative mess but a historical one. The tablets are now smashed but are not remade, leaving Israel with an empty ark ever after. Bloom takes the author of $\mathrm{J}$ to be a great advocate of the monarchy of Judah's King Solomon, but this leaves J suggesting that the ark in Solomon's Temple in Jerusalem does not really contain the sacred tablets.

This would in turn raise the question of why any ark was ever made in $\mathrm{J}$, since there was nothing to put in it. The ark is in fact an important part of $\mathrm{J}$, and it is built precisely to house the tablets. But this is no problem to Bloom and Rosenberg, because they also left out the subsequent $\mathrm{J}$ stories in which the ark was mentioned.

Putting the golden calf story in J also leaves $\mathrm{J}$ attacking the priest Aaron, for this story depicts Aaron as the maker of the golden calf. But the Jerusalem Temple priesthood traced themselves as descendants of Aaron, and that priesthood was intermarried with the royal family of David and Solomon. The story is thus a political criticism of Jerusalem's priesthood and, by association, its royal family. But this author is supposed to be King 
Solomon's great advocate according to Bloom. If his advocate wrote this story, it is no wonder that Solomon's kingdom split. With friends like that, as they say, who needs enemies!

Incredibly, Bloom and Rosenberg left out the J text of the Ten Commandments (Exodus 34:14-29). This is unexplained and inexcusable. (It also makes one wonder what Bloom and Rosenberg thought was written on those tablets that were smashed.)

It gets worse. J contains what is arguably the most important passage in the Torah, the lines in which the deity reveals to Moses the key formula of the divine character. It is the closest we ever come in the Hebrew Bible to knowing the essential character of Yahweh, and it is a passage that is quoted and alluded to in works by other biblical authors following J. But, again incredibly, Bloom and Rosenberg left this J passage out. In it, the deity reveals himself as:

\begin{abstract}
Yahweh, merciful and gracious God, long-forbearing and abundant in faithfulness and truth, storing up faithfulness for thousands, bearing offence and crime and sin, though not wiping clean, visiting the offence of fathers on sons and grandsons, on third generation and on fourth.
\end{abstract}

It is enigmatic, remarkable, comforting, fearful, beautiful - worth a book in itself. But Bloom and Rosenberg left it out, and there were severe consequences. See below.

On the other hand, they put in the story of Jacob's wrestling with God (Genesis 32). It is a great story, mysterious, powerful, and exciting. But it is not J. In this story Jacob asks the being with whom he has struggled what his name is, and this being refuses to say his name. That is the mark of $E$, the hiddenness of the divine name until the time of Moses. Also in this story Jacob names the location of the struggle "Peni-El." The story is thus the etiology of the name of Penuel, which was a city in the Northern kingdom of Israel, founded by its king, Jeroboam. But Bloom relates J's stories and author to the Southern Israelite kingdom of Judah, ruled by king Rehoboam. Bloom has the wrong text, the wrong author, the wrong country.

The list goes on, but these examples should be sufficient to begin to convey how serious the problem is. Bloom and Rosenberg did not just 
miss a line here and there. They left out major sections of the work, and they mistakenly included lengthy stories that were written by other authors. IT IS NOT J. Bloom and Rosenberg have the wrong text.

The TRANSLATION. Incredible as it may seem, it appears that neither Rosenberg nor Bloom has ever had a proper training in biblical Hebrew. Theirs appears to be the Hebrew of the modern American synagogue school plus perhaps some modern Israeli Hebrew, and they really seem to be unaware of how different and how difficult the language of the Bible is. In a lengthy review in Commentary, Professor Robert Alter, of the University of California, Berkeley, has made an attempt at conveying how terribly erroneous Rosenberg's text is. Alter himself is not a biblical scholar and does not claim to be one. Still, his knowledge of the Bible and of biblical Hebrew was more than sufficient to see the distance between what the Bible says and what Rosenberg thinks it says. Jack Miles, too, in a review in Books and Religion, has taken pains to explain even to readers who do not know Hebrew how out of touch this "translation" is with what appears in the original. I therefore refer the reader to Miles's and to Alter's catalogues of Bloom's and Rosenberg's mistakes - from calling the taskmasters of the Exodus story "policemen" to calling the J author a gevurah, which Bloom thinks means "great lady." (It means "courage.") Beyond that, I want to underscore the point that Rosenberg and Bloom simply lacked the basic competence in the language of the Bible to have taken on the difficult task of Bible translation in the first place.

Rosenberg refers to the shifting tenses from past to present to past, saying that the Hebrew tense is "often indistinct." He really appears to be unaware that there are no past, present, and future tenses in biblical Hebrew. These categories are only properly used for teaching children who are just beginning to learn the Bible in Hebrew and who are not yet ready to learn the complexities of the Hebrew participle and perfect and imperfect tenses.

Rosenberg's senseless transcriptions of Hebrew, his failure to recognize puns that bind units of the story together, his introduction of words and phrases that simply do not exist in Hebrew, his utterly mistaken sense of the feeling of narration in biblical Hebrew, its tenses, its way of directing the reader's attention - all of this, plus the sheer quantity of absurd transla- 
tions, makes the work of translation a disaster. They do not add up to merely a large number of mistakes. They mean that this man does not know what biblical Hebrew is about. If Rosenberg had been Moses' translator instead of Aaron, the Israelites would still be in Egypt.

I do not joke lightly. It is frightening to think that people are reading this man's words and thinking that they are reading something that is in the Bible. IT IS NOT THE BIBLE.

It gets worse. There is still the matter of the claims that Bloom made about this text. Most important, by his own account, is his presentation of J's view of God. He says, "J is the most blasphemous writer who ever lived ..." God in J is "always getting out of hand." God in this work is characterized primarily by vitality rather than by the more usual divine qualities of holiness, righteousness, moral behavior, and love for humankind. Where does Bloom find all of this in biblical J? In an interview he explained that this is "a God who, for no reason at all, attempts to murder his own messenger or prophet Moses, a God who sends a nameless one among the angels for an all-night terrible wrestling match which cripples Jacob forever, a God who on the top of Sinai goes half-mad with anguish at having to extend his blessing to the whole host of the people," who becomes "crazed" and "dangerous" during the forty years in the wilderness.

What are we to make of this?

(1) The reference to God's trying to murder Moses appears to be a misunderstanding of a strange little (only three verses long) story in Exodus (4:24-26) following the burning bush story. It is one of the most difficult stories in biblical narrative because it uses pronouns with unclear antecedents, so it is not clear who is doing what to whom or why. Nobody is sure what these three verses mean. One of the few things of which we can be sure, though, is that they are not about a murder, for the author of $\mathrm{J}$ distinguishes murder from killing in general, and from the deity's taking of human life in particular, using different words for each. This text, even in Rosenberg's very loose translation, does not speak of murder. Yet Bloom was prepared to picture this author as actually composing a story of God's trying to murder Moses. And why does God want to do this? "For no reason at all." Great interpretation. Great scholarship. 
(2) The story of the wrestling match with God (no reference to an angel here), as I said above, is not part of J. It is from another work, E, and Bloom has the wrong author here.

(3) I really cannot see what story Bloom is even thinking of when he talks about God going "half-mad" at Sinai. There is simply no such thing, either in the original or even in the confused text of Rosenberg's and Bloom's, which is about forty percent $\mathrm{E}$ in any case. Particularly if Bloom means the golden calf story here, he has once again confused an $\mathrm{E}$ story for $\mathrm{J}$.

(4) Nor is it fair to call God "crazed" during the forty years of wandering in the wilderness, especially since the text of Rosenberg and Bloom leaves most of the $\mathrm{J}$ wilderness stories out, leaving only a few stories for the whole forty years. (And much of that is E and P.)

In short, Bloom is lost in this material. He says that $\mathrm{J}$ presents a picture of God that is different from that of every other biblical writer, and he does not realize that he is basing this claim on the pictures of some of those other writers. He thinks that Yahweh in J is a wild, often hostile God, "a God who cannot be discussed in terms of affection for us ..." But he bases this on a text that leaves out the key J scene in which Yahweh is explicitly pictured as: "merciful and gracious, long-forbearing, abundant in faithfulness and truth, storing up faithfulness for thousands."

If one is going to be outrageous about the deity, one should at least be sure to have one's data straight.

Then there is the question of the author of J possibly being a woman. This clearly is what brought Bloom's book so much attention. The Newsweek story's title was "The Woman Who Invented God." U.S. News \& World Report's title: "Murder She Wrote." Time: "Ms. Moses." The New York Review of Books: "It's a Girl!"

On one hand, I am happy that someone chose to follow the suggestion I made of this possibility in Who Wrote the Bible? On the other hand, Bloom has made a circus of this point, offering absurd evidence. As the old line goes, in Bloom's book "what is good is not original, and what is original is not good." I proposed that the author of J might be a woman, as Alter put it, "tentatively and cautiously." I was merely recognizing that the sex of the author is an important element that is usually left out of the discussion. I said that, since the other major works of the Five Books of Moses 
(E, $\mathrm{P}$, and $\mathrm{D}$ ) appeared to be by priests, the authors were presumably male, because the priesthood in biblical Israel was limited to men; but J was not priestly and therefore could possibly have been by a woman (of the noble class). Bloom urged this point more "boisterously" (his term), but his case is no case at all. His argument that the J account of the creation of Eve is six times longer than the creation of Adam proves nothing at all about the sex of the author. (Also, his arithmetic is wrong.) I, too, noted that the J stories are particularly concerned with and sensitive to women. But, if I were going to mount a full defense of the idea that this author was a woman, I would at least have come to terms with the fact that it is precisely in $\mathrm{J}$ that the deity imposes a curse on women that:

Your desire will be to your man, and he will rule over you.

(Gen. 3:16)

It is possible to imagine a woman writing this line in that society, but it takes some explaining. Bloom got out of the explaining because he used Rosenberg's absurd translation of this line:

To your man's body your belly will rise, for he will be eager above you.

The Hebrew contains no reference to a man's body, no reference to a woman's belly, no rising, no being eager, and no being above anyone. Rosenberg actually says at one point, "Where the translation appears to depart from a literal word-for-word slavery, it is for the sake of accuracy: to convey syntactical and contextual nuances in the Hebrew text." Nonsense. This translation is a figment of Rosenberg's imagination, and it saves Bloom from a blatant problem that any reader would have been able to see in his claim about the author's sex.

Here, regrettably, the matter of ignorance must be joined to the matter of integrity. As far as I know, Jack Miles, writing in the Los Angeles Times, was the first to expose Bloom's work on this and other points. Miles quoted Bloom's announcement: 
For J, we have a choice of myths, and I boisterously prefer mine to that of the biblical scholars. I will put all my cards on the reader's desk here, face up. My J is a Gevurah [sic] ("great lady") of post-Solomonic court circles, herself of Davidic blood, who began writing her great work in the later years of Solomon...

To which Miles commented:

Boisterously, let me suggest that Bloom's most important card is not on the reader's desk at all. Bloom has lifted the notion that the author of J may have been a woman from Richard Elliott Friedman, who proposed it in 1987 in his book "Who Wrote the Bible?" Bloom cites this work in passing but does not credit Friedman for the provocative hypothesis that Bloom has placed at the center of his own work.

Baruch Halpern, too, in response to the publisher's claim that this was "a bold new interpretation," said, "The idea that J's author was female may be bold, but it isn't new, and it isn't Bloom's. . . . In flagrante, this is theft of intellectual property" (Bible Review, February, 1991). I appreciate Miles's and Halpern's and Alter's crediting my work, and I beg the reader not to take my critique of Bloom here as merely reflecting my being annoyed at his "lifting" from me. I am indeed annoyed, but the issue is more serious than that, and in any case I am in good company. Bloom failed to credit many others properly as well. Most serious among his omissions: this project has been done before. It was done under the title The Yahwist: The Bible's First Theologian by Peter Ellis, published in 1968. This was a book containing the text of $\mathrm{J}$, together with a theological and literary analysis. It was done again in 1989 in a different format under the title The Bible's First History by Robert Coote and David Ord. Bloom does not mention these. Either he was unaware that his project had been done already, or he was, as Miles kindly put it, not "up front" about it.

In the face of Bloom's crude arrogance toward biblical scholarship, either of these is inexcusable. Bloom prints J separately and comments on its literary characteristics. That's been done before. He focuses especially on its view of God. That's been done before. He says it's by a single 
writer. That's been said before. He says the writer may have been a woman. That's been said before. He connects her with the noble class. That's been said before. He says it's from the Solomonic era. That's been said before. He relates it to the Court History of David. That's been said before. He says it's great literature. That's been said before. He compares it to Homer. That's been said before. And then Bloom denigrates biblical scholarship for having missed the insights that he claims to have given us!

It is unpleasant to have to criticize another scholar's integrity, but Bloom has acted disgracefully toward the real scholars of the Bible, and he really must be taken to task for this. Also, more to the point of the present essay, the matter of integrity here is particularly connected to the matter of ignorance of the Bible. Here is a case in point: the matter of Bloom and Rosenberg having the wrong text of J. Rosenberg wrote (328) "The scholarly sources I followed for extracting the $\mathrm{J}$ text are the standard authorities in the field, as refined most recently by Martin Noth and superseded by the insights of Harold Bloom." Allowing, for the moment, the supersession of Bloom's insights, the fact is that Martin Noth's work was published in 1948. Rosenberg has simply missed the last forty years of discoveries, and this, in part, is responsible for his having the wrong text. Here was Bloom's answer when this was pointed out to him:

And then they will be revised again, my dear, and they will be revised again. But that is not the issue, and I am not entering the lists as one more person trying to take part in these mimic wars in biblical scholarship.

I beg your pardon? Bloom and Rosenberg cared about being current in biblical scholarship when they assured their readers they were getting J "as refined most recently by Martin Noth." But when it was pointed out that Noth's work was from 1948, suddenly we were assured that biblical scholarship is just a flux of ever-revising opinion. And Bloom does not want to "enter the lists"! But he has entered the lists. His stance that he is doing something higher than Higher Criticism is both pretentious and misleading. He tried to identify which parts of the Bible are J, just as the scholars in this field have done, and that is the necessary underpinning of his whole project. The problem is that he got it wrong. It is not J. "Mimic 
wars"? First, Bloom does not give credit to biblical scholars when he finds out that they have already said what he wants to say. Then he belittles their work when it belies what he wants to say. Shame on him. When his error was revealed, his response only got him in deeper. He forgot the first law of holes: When you're in one, stop digging.

As I said at the beginning, my interest in this book is as a measure of the ignorance of the Bible in our culture at present. And the Bible, in turn, is perhaps the best measure of the degree of our general cultural illiteracy, which is of critical concern of late. It is, after all, the best known book in the world, the only book that is still quoted with any frequency at all, perhaps more than all the works of Shakespeare combined. For me, therefore, the problem is not just that this particular book by Bloom and Rosenberg is bad. The problem is that the book is so bad that there is a question of how this could have happened. How did Bloom and Rosenberg think that they could do this work? How did their publisher not have any idea of the quantity and seriousness of the problems with it? How did much of the media coverage and reviews come to take it seriously and even praise it? I think that the explanation may lie in the point with which I opened this essay, namely that people are surprised to learn how much we really know about the Bible and about the world that produced it. Even sophisticated, well-read persons are liable to think that the Bible is opinion-prey. Many believers made all sorts of unproven assumptions about it for centuries. Then, when it was opened to rational questioning and scientific challenges in recent centuries, the non-believers were allowed to make their assumptions as well. One opinion is as valid as another.

Thus the publisher of Bloom's and Rosenberg's book was well-meaning but did not consult with any biblical scholar, either to check the translation for basic reliability or to check Bloom's claims. And the publisher, unaware that this had been done before, announced that "for the first time" J had been lifted out of the surrounding texts. Of four laudatory comments printed on the back cover of Bloom's book, none was by a biblical scholar. Grace Schulman wrote, "Bloom's vision that the J author was a priviliged and erudite woman is startling but convincing. ..." Northrop Frye wrote, "The Book of J clearly highlights one of the major problems in Western culture: the fact that the Jehovah [sic] of the Old Testament is 
not a theological god at all but an intensely human character as violent and unpredictable as King Lear." And Richard Howard wrote, "To read Bloom here is to become, a while, incandescent." In a New York Times review, Frank Kermode praised the book as Bloom's best, only questioning some of its translations, which is curious since Kermode does not know Hebrew. A second New York Times review appeared by Christopher Lehmann-Haupt, who praised "this book of surpassing originality." Naturally people were interested and bought the book.

The Los Angeles Times review by Jack Miles, meanwhile, was critical; but that is just the point: Miles, the book review editor of the L.A. Times, also has a Ph.D. from Harvard in Bible. It has been followed by a string of critical reviews by persons in the field and in related fields. As for other biblical scholars' reactions in general, some are annoyed, as I said above, especially since they are left having to clean up the mess that these men have made for the next few years. (How would any other professional act if it were his or her field being treated this way?) Others are amused. I, for one, don't feel amused anymore, because it's the Bible, and it hurts to see it trashed in this way. Men and women become biblical scholars, for the most part, because - each in his or her own way - they feel the riches, the power, the beauty, the spirit, the relevance, the value of the book. For all the accusations-mostly unjust - that they are only cutting and excavating and counting, most biblical scholars I know have developed a special kind of humility toward the Bible: Aware of the enormity of the task and of the complexity of it all, they come to feel that their individual contributions are small pieces of the puzzle, and they have much respect for the few who have produced great syntheses of it all. But many of the nonBible people like Bloom and Rosenberg, precisely because of their ignorance of this, know no fear and certainly no such humility. I cannot just be amused, because Bloom and Rosenberg have taken ignorance and arrogance too far. They have taken the first great writer and cut his or her work up, broken its continuity, left out important parts, mixed in the work of other writers, mistranslated it so badly that it is no longer itself, and misrepresented its picture of God.

What good can come of this? I believe that Bloom's and Rosenberg's book is so terribly flawed that it is not even of heuristic value. But, albeit ironi- 
cally, some real good can come of this - not from the book but from the phenomenon of this book. The value could become: this is the book that showed that this ignorance had finally gone too far. It was one thing when the popular books of Bible speculation were about finding the ark and about space ships in Ezekiel. Such books were not generally regarded as intellectually respectable. But it is another thing when distinguished scholars claim to shed light on the Bible, and they know not that they know not.

This silliness masquerading as scholarship must stop. It is less than outrageous. It is just plain silly. Taking out the rubbish is part of our job in scholarship, and in time all of this rubbish will be taken out. In the meantime, though, it is tedious; and it is unfortunate that this is taking up the time of scholars and of people who sincerely want to know what it is about the Bible that has made it the book and the force that it is. Given how important the Bible is to so many, the degree of ignorance about it is frightening. The greatest good that can come from this book is if it will expose this depth of ignorance and trouble enough people that they will want to correct it. Hopefully the people who paid $\$ 22$ for it will be annoyed enough to seek out the real $\mathrm{J}$ and the real Bible so that their time and money will not have been completely wasted.

Buyer beware. Before reading a book that purports to shed new light on the Bible, check the credentials of those who wrote it. Find out what other qualified persons have to say about it. Read more than one person's view on any given subject. And don't trust anybody who makes assertions without citing the evidence from the text for you to check for yourself.

It is well worth the trouble. After all, it is the Bible, for heaven's sake. 